\title{
Microbiological and physical-chemical characteristics of honeys from the bee Melipona fasciculata produced in two regions of Brazil
}

\section{Rachel Torquato Fernandes $^{1^{*}} \cdot{\text { Ivone Garros } \text { Rosa }^{2} \odot \text { Ana Carolina Conti-Silva }}^{3} \odot$}

${ }^{1}$ Instituto Federal de Educação, Ciência e Tecnologia do Maranhão (IFMA), 65075-441, São Luís, MA, Brasil. E-mail: racheltroquato@ifma.edu.br. ${ }^{*}$ Corresponding author.

${ }^{2}$ Núcleo de Imunologia Básica Aplicada, Universidade Federal do Maranhão (UFMA), São Luís, MA, Brasil.

${ }^{3}$ Departamento de Engenharia e Tecnologia de Alimentos, Instituto de Biociências, Letras e Ciências Exatas (Ibilce), Universidade Estadual Paulista (Unesp), São José do Rio Preto, SP, Brasil.

\begin{abstract}
The honey from Tiúba bees (Melipona fasciculata) is commercially important in the Brazilian state of Maranhão. However, the absence of any specific legislation for this kind of honey is an obstacle to its increased production and commercialization. Determining the microbiological and physical-chemical characteristics of different Tiúba honey can inform the elaboration of specific legislation. Thus, honey samples from two Water Catchment Areas in Maranhão (Munim and Pericumã, sample size 20 for each) were collected and submitted for microbiological analysis (total coliforms, thermotolerant coliforms, molds and yeasts, Clostridium sulfite reducers and Salmonella sp.) and physical-chemical analysis (moisture content, reducing and non-reducing sugars, insoluble and soluble solids, ash content, acidity and pH). Most of honeys sampled were suitable for human consumption, except for one sample from Pericumã. Honeys from the two water catchment areas presented differences in some physicochemical characteristics, which can be attributed to the botanic, soil and climatic diversity of the two areas. Still, these Tiúba honey samples did not fall within the Brazilian legislation for Apis mellifera honey for some of the physicalchemical characteristics, and so is not properly regulated, thus reinforcing the need for specific legislation for this type of honey.

Key words: Melipona fasciculata, honey, Munim, Pericumã, Brazil, microbiological characteristics, physical-chemical properties, quality standard.
\end{abstract}

Características microbiológicas e físico-químicas de méis de abelha Melipona fasciculata produzidos em duas regiões do Brasil

RESUMO: O mel de Tiúba (Melipona fasciculata) tem importância comercial na região do estado do Maranhão, no entanto a ausência de uma legislação específica para este mel entrava a ampliação de sua produção e comercialização. Dessa forma, faz-se necessário determinar as características microbiológicas e físico-químicas de méis de Tiúba, com o objetivo de fornecer subsídios para a elaboração de uma legislação especifica. Assim, amostras de méis provenientes de duas bacias hidrográficas do Maranhão (Munim $n=20$, e Pericumã $n=20)$ foram coletadas e submetidas às análises microbiológicas (coliformes totais, coliformes termotolerantes, bolores e leveduras, Clostridium sulfito redutores e Salmonella sp.) e físico-químicas (umidade, açúcares redutores e não redutores, sólidos insolúveis e solúveis, cinzas, acidez e pH). A maioria dos méis apresentou-se adequado microbiologicamente ao consumo humano, exceto uma amostra de mel proveniente de Pericumã. Os méis provenientes das duas bacias hidrográficas apresentaram diferenças em algumas características fisico-químicas, o que pode ser atribuido à diversidade botânica, edáfica (solo) e climática das duas bacias. Ainda, os méis de Tiúba não se adequaram à legislação brasileira de Apis mellifera para algumas características físico-químicas, o que não permite sua regulamentação e, assim, reforça a necessidade de legislação especifica para este tipo de mel.

Palavras-chave: Melipona fasciculata, mel, Munim, Pericumã, Brasil, características microbiológicas, propriedades fisico-químicas, padrão de qualidade.

\section{INTRODUCTION}

Bee honey is the natural, sweet substance produced by honeybees from the nectar of blossom or from the secretion of living parts of plants or excretions of plant sucking insects on the living parts of plants. Honeybees collect these substances, transform them and combine them with their own specific substances and then store and leave them in the honeycomb to ripen and mature (PIRES et al., 2009; FEÁS et al., 
2010b). Its composition depends on the nectar and on the physiology of the specie of the bee that prepares it, giving it its own physical, chemical, biochemical and sensorial characteristics, besides those from the climatic and soil conditions, handling practices and manipulation in the processing, all of which interfere in the physical-chemical properties and product quality (ESTEVINHO et al., 2016, ARAÚJO et al., 2017). Also, bees honey is a product used in different cultures over time due to its nutritional and therapeutic properties, such as its antimicrobial, antitumor, anti-inflammatory and antiviral properties (KWAKMAN et al., 2010; JAGANATHAN et al., 2011; WATANABE et al., 2014).

According to its entomological origin, honey may be from the species Apis mellifera, which is the most widely known and commercially available worldwide, or from meliponines, which are commonly known as stingless bees without sting, or native bees. Among the meliponines, the Tiúba bee (Melipona fasciculata Smith), a native Brazilian pollinating species of natural ecosystems occurring in transitional regions between the Amazonian Forest, the Cerrado and the Caatinga, stands out as a promising species for producing honey, currently kept both in cottage industries and also, at an improved technological level, on small farms in the state of Maranhão (BARROS, et al., 2013; CARVALHO et al., 2016). Its honey is much appreciated in the region for fresh consumption, having a more acid taste, higher fluidity and lower viscosity, in addition to its medicinal appeal, which increases and raises the price of the product compared to Apis mellifera honey (OLIVEIRA \& SANTOS, 2011; HOLANDA et al., 2012). In local markets, the price of Melipona fasciculata honey is usually the double of the Apis mellifera honey, and it may be higher during the off-season.

The production and commercialization of honey from meliponines is still limited when compared to the Apis genus and; although, some studies have already been developed (GUERRINI et al., 2009; SOUZA et al., 2009), there is still a lack of knowledge about its characterization, making it difficult to establish an official standard of quality needed to expand its production and marketing. The study of its microbiological characterization and physicochemical composition is important for the certification process, which determines quality and origin (geographic or entomological), assists in inspection and the results can be compared with official standards (FEÁS et al., 2010a; IGLESIAS et al., 2012). However, quality indicators established in Brazilian legislation refer to parameters for honey from the Apis mellifera species (BRASIL, 2000), which do not correspond to those observed in meliponine honey. And any attempt to apply these established norms generates problems in evaluating the quality of the honey produced by meliponines (SOUZA et al., 2009; CAMARGO et al., 2017).

So providing support for the creation of a standard identity and specific quality for stingless bee honey is crucially increases knowledge of the product, and thus allows supervision by food control authorities which, in turn, guarantees the quality of the honey for consumers. Therefore, the aim of this study was to determine the microbiological and physical-chemical properties of Tiúba honey produced in two water catchment areas in the Brazilian state of Maranhão (called Munim and Pericumã) also seeking to identify differences related to the geographic origin of the products.

\section{MATERIALS AND METHODS}

In the period from November 2014 to October 2015, forty samples of Tiúba honey were collected. Twenty samples were taken from four municipalities in the Munim Water Catchment Area: Belágua $(\mathrm{n}=2)$, Morros $(\mathrm{n}=12)$, São Benedito do Rio Preto $(\mathrm{n}=1)$ and Urbano Santos $(\mathrm{n}=5)$. The other twenty samples came from six municipalities in the Pericumã Water Catchment Area: Bequimão $(\mathrm{n}=9)$, Cajapió $(\mathrm{n}=1)$, Palmeirândia $(\mathrm{n}=3)$, Peri-Mirim $(\mathrm{n}=5)$ and São Vicente Ferrer ( $\mathrm{n}$ $=1)$. They were collected from the two Water Catchment Areas because these two areas have diverse characteristics regarding vegetation, water resources and edaphoclimatic characteristics, as well as different human production systems, factors directly related not only to production but also to the characteristics of honey.

Individual Tiúba honey samples were extracted directly from the colonies under partial asepsis using $60 \mathrm{~mL}$ disposable syringes, then packed in glass vials $(500 \mathrm{~mL})$ with polyethylene screw caps and sterilized by autoclaving. Afterwards, they were placed in styrofoam boxes, kept at a temperature of $25^{\circ} \mathrm{C}$, unexposed to light until the microbiological and physical-chemical analyses at the Universidade Federal do Maranhão (UFMA), analyses that were always performed fifteen days after collection.

The microbiological analyses were done according to Brazilian legislation (BRASIL, 2001; ICMSF, 2002), checking microorganisms that are indicators of the sanitary quality of food 
or that can cause foodborne illnesses. Thus, tests were performed for counts of total coliforms, thermotolerant coliforms, molds and yeasts, Clostridium sulfite reducers and Salmonella sp.

$$
\text { Analyses required by Brazilian }
$$

legislation (BRASIL, 2000) for physical-chemical characterization of the honeys are divided into maturity indicators (moisture, reducing and nonreducing sugars), purity (insoluble solids and ash) and deterioration (acidity). The following methods were used for this analysis: moisture and free acidity (AOAC, 2000); reducing sugars, non-reducing sugars, insoluble solids and ash (CAC, 2001). In addition to the analyses required by legislation, complementary analyses of soluble solids and $\mathrm{pH}$ (IAL, 2005) were performed, since they are also relevant for the characterization of honey, being, respectively, indicators of purity and deterioration. All physicalchemical analyses were performed in triplicate.

The mean values of the physical-chemical characteristics of the honey samples from the two catchment areas were compared using the Student t-test, at a significance level of 0.05 . For the $\mathrm{pH}$ and ash variables, the t-test was applied to independent samples assuming different variances ( $p$-value of the Levene test $\leq 0.05$ ), while, for the other variables, the t-test was applied for independent samples assuming equivalent variances (value of $p$ of the Levene test $>0.05$ ). Also, the means of the physicalchemical characteristics were submitted to principal component analysis (PCA) for characterization of the honey samples from different locations. The analysis was performed using the correlation matrix, whose $\mathrm{p}$-value for the Bartlett sphericity test was $<0.001$, indicating that PCA is an appropriate analysis to be applied to the data. All statistical analyses were performed using the Statistica 7.0 software (StatSoft, Inc), with the exception of the Bartlett sphericity test, which was performed in the PASW Statistics for Windows Version 18.0 software (SPSS Inc.).

\section{RESULTS AND DISCUSSION}

Samples of Tiúba honey did not show any contamination by total and thermotolerant coliforms, nor was there any presence of Clostridium sulfite reducers and Salmonella sp. (Table 1). However, in one of the samples from the Pericumã Water Catchment Area (5\%), the total count of molds and yeasts reached $105 \mathrm{CFU} . \mathrm{g}^{-1}$, being above the maximum recommended by Brazilian legislation $\left(100 \mathrm{CFU} \cdot \mathrm{g}^{-1}\right)$. All the other samples were within the same legal recommendations for molds and yeasts. Tiúba honey samples collected in the Brazilian State of Piaui also had low contamination levels of molds and yeasts (1.88CFU.g $\mathrm{g}^{-1}$ ) (MONTE et al., 2013).

Microbiological contamination of honey can be caused by pollen microbiota, from the bee itself, or by failures in the hygiene of the manipulator during processing of the product. Osmophilic microorganisms, such as molds and yeasts, present the greatest risk to the quality of the honey because they can survive in acidic conditions and are not inhibited by sugar (GOIS et al., 2013). So, the above results are important because they indicate that the collection, processing and packaging have met the hygienic and sanitary requirements.

Furthermore, there is little likelihood of fermentation of honey that has mold and yeast counts below 100CFU.g ${ }^{-1}$, provided it is stored in a dry environment (DENARDI et al., 2005). However, when levels are above the recommended values, the product tends to become vulnerable to fermentation since sugar degradation by microorganisms results in the formation of ethanol and carbon dioxide, changing the sensory characteristics and physicalchemical properties of honey, which affects quality.

The mean moisture content was statistically higher $(\mathrm{p} \leq 0.05)$ for honey from the Pericumã Water Catchment Area than the Munim (Table 2), the variation being 19.2 to $26.6 \%$ in the Munim region

Table 1 - Percentage of suitability of Tiúba honey, by Water Catchment Area $(\mathrm{n}=20)$, in relation to recommendations for microbiological parameters.

\begin{tabular}{|c|c|c|c|}
\hline \multirow[t]{2}{*}{ Parameters } & \multicolumn{2}{|c|}{ 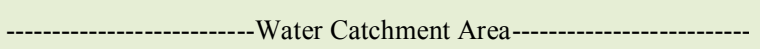 } & \multirow[t]{2}{*}{ Recommendation ${ }^{*}$} \\
\hline & Munim & Pericumã & \\
\hline Coliforms $35-45^{\circ} \mathrm{C}\left(\mathrm{NMP} \cdot \mathrm{g}^{-1}\right)$ & $100 \%$ & $100 \%$ & $100^{*}$ \\
\hline Molds and yeasts (CFU.g $\left.{ }^{-1}\right)$ & $100 \%$ & $95 \%$ & $100^{* *}$ \\
\hline Clostridium sulfite reducers & $100 \%$ & $100 \%$ & Absence \\
\hline Salmonella sp (in 25g) & $100 \%$ & $100 \%$ & Absence \\
\hline
\end{tabular}

*BRASIL (2001). ${ }^{* *}$ ICMSF (2002). Both references to Apis mellifera honey. 
Table 2 - Mean \pm standard deviation of physical-chemical characteristics of Tiúba honey, by Water Catchment Area $(\mathrm{n}=20)$.

\begin{tabular}{|c|c|c|c|}
\hline \multirow[t]{2}{*}{ Characteristics } & \multicolumn{2}{|c|}{---------------------------Water Catchment Area--------------------------. } & \multirow[t]{2}{*}{ Legislation $^{*}$} \\
\hline & Munim & Pericumã & \\
\hline \multicolumn{4}{|l|}{ Maturity indicators } \\
\hline Moisture (\%) & $23.7^{\mathrm{b}} \pm 1.86$ & $27.2^{\mathrm{a}} \pm 1.52$ & Maximum 20 \\
\hline Non-reducing sugars ( $\%)$ & $7.2^{\mathrm{a}} \pm 5.65$ & $8.5^{\mathrm{a}} \pm 4.76$ & Maximum 6 \\
\hline Reducing sugars (\%) & $52.6^{\mathrm{a}} \pm 6.44$ & $50.1^{\mathrm{a}} \pm 5.26$ & Minimum 65 \\
\hline \multicolumn{4}{|c|}{ Purity and deterioration indicators } \\
\hline Insoluble solids $(\%)$ & $0.11^{\mathrm{a}} \pm 0.09$ & $0.09^{\mathrm{a}} \pm 0.07$ & Maximum 0.1 \\
\hline Soluble solids $\left({ }^{\circ} \mathrm{Brix}\right)$ & $73.9^{\mathrm{a}} \pm 2.02$ & $72.8^{\mathrm{a}} \pm 1.53$ & Without reference \\
\hline Ash (\%) & $0.52^{\mathrm{a}} \pm 0.26$ & $0.12^{\mathrm{b}} \pm 0.10$ & Maximum 0.6 \\
\hline Acidity (meq. $\mathrm{kg}^{-1}$ ) & $27.5^{a} \pm 20.45$ & $30.6^{\mathrm{a}} \pm 19.52$ & Maximum 50 \\
\hline $\mathrm{pH}$ & $4.9^{\mathrm{a}} \pm 0.95$ & $3.8^{\mathrm{b}} \pm 0.34$ & Without reference \\
\hline
\end{tabular}

*BRASIL (2000), for Apis mellifera honey. Different letters in the same row indicate the means are statistically different by Student's t test $(\mathrm{p} \leq 0.05)$.

and 24.1 to $29.1 \%$ in the Pericumã region. Moisture is an indicator of honey maturity, which is influenced by the botanical origin of the nectar, the climatic characteristics of the region, (mainly the relative air humidity) and also crop management (BRASIL, 2000; NASCIMENTO et al., 2015; SOUSA et al., 2016). The Munim region presents average temperatures, rainfall and annual mean relative humidity lower than the Pericumã region (GEPLAN, 2002), which may have contributed to the significant moisture difference between the honey from the two Water Catchment Areas.

Similar results were reported for meliponine honey from semiarid Brazil 23.9 to 25.9\% (ALMEIDA-MURADIAN et al., 2013) and 23.9 to $28.9 \%$ (SOUSA et al., 2013), and also for honey from Tiúba, moisture content ranging from 21.4 to $27.5 \%$ (HOLANDA et al., 2012). Although, the mean humidity values for the Tiúba honey from the two Water Catchment Areas are within the range expected for groups of stingless bees, these values do not fit into the framework established by the Brazilian legislation, whose reference is Apis mellifera honey, with a maximum moisture content of $20 \%$ (Table 2 ).

There was no statistically significant difference $(p>0.05)$ in the mean values of nonreducing sugars and reducing sugars between honey samples from the two areas (Table 2). Sugars are the major constituents of honey, with a predominance of the reducing monosaccharides glucose and fructose which influence viscosity, crystallization, hygroscopicity and antibacterial activity. As indicators of quality, sugars are related to honey maturation, and thus, high levels of non-reducing disaccharides, or sucrose, that have not yet been converted to glucose and fructose may be indicative of premature harvesting of the product (BRASIL, 2000; ALMEIDA-MURADIAN et al., 2013). The honey harvested in this research was not premature, i.e. the high levels of non-reducing sugars were not due to the collection of immature honey or 'green honey', as the criterion of only extracting honey from capped honey-filled pots was followed.

Values of non- reducing sugars and reducing sugars reported in Scaptotrigona bipunctata honey were 3.2 to $5.5 \%$ and 58.1 to $61.4 \%$ respectively (OLIVEIRA \& SANTOS, 2011), and in Melipona scutellaris honey ranged from 2.2 to $4.7 \%$ and 43.7 to $66.5 \%$ (CAMPOS et al., 2010). Again, the mean contents of non-reducing and reducing sugars for Tiúba honey from the two areas in this study are within the expected range for groups of stingless bees. However, according to Brazilian legislation for Apis mellifera honey (Table 2), these values are not within permitted levels. The average sugar content of Tiúba honey being below the recommended level for Apis mellifera honey can, in fact, be considered a benefit to the health of the consumer, and, for this reason, it would be interesting to adapt the legislation for products like this one that require such a change.

The mean values of insoluble solids and soluble solids were statistically the same $(p>0.05)$ for honey from the two areas (Table 2). Insoluble solids are indicators of purity and their analysis provides information on the hygienic control of honey, as it detects impurities like cerumen and plant residues, parts of the bee's body and, also, soil particles, which may be related to its harvesting and 
processing (BRASIL, 2000). Lower values than those reported in this study for insoluble solids were found in honey from Melipona scutellaris (0.001 to $0.019 \%)$ (ANACLETO et al., 2009), while similar results were reported for soluble solids in Tiúba honey from the Brazilian state of Pará, which ranged from 73 to 74\% (SILVA et al., 2013).

The mean ash content was statistically higher $(\mathrm{p} \leq 0.05)$ in the honey samples from the Munim Water Catchment Area (Table 2). However, the two sets of honey samples are in compliance with the legislation for Apis mellifera honey. Studies with honey from Tetragonisca angustula bees (ANACALETO et al., 2009) and of several undefined species of meliponines (NASCIMENTO et al., 2015) also showed variations in the ash content, from 0.2 to $0.6 \%$ and 0.1 to $0.3 \%$, respectively.

The ash content is a purity indicator, which expresses if the honey is rich in minerals and is directly related to the color of the product. The minerals present in honey can be influenced by the species of bee, the botanical species foraged, climatic and soil conditions of the region and the actions of the honey producer during honey processing. Like ash analysis, it is possible to identify processing failures such as lack of hygiene, and the elimination of the decanting and filtration stages (BOGDANOV et al., 1999). In the case of this current research, the average ash content is within the recommended legal limits for Apis mellifera honey (Table 2).

There was no significant statistical difference $(\mathrm{p}>0.05$; Table 2$)$ between the mean values for acidity in the honey samples from the two regions and they met the requirements of the Brazilian legislation for Apis mellifera. Acidity is an indicator of deterioration related to the fermentation of honey through inadequate storage, it is important in the stability of the product, minimizing the action of microorganisms, and it tends to reduce with the maturing of honey (BRASIL, 2000). Naturally, the acidity results from the presence of organic acids, especially gluconic acid, produced by the glucose oxidase enzyme acting on the glucose (ANDRADE, 2006). Other studies with stingless bees had mean acidity levels of 22.8 to $42.7 \mathrm{meq} \cdot \mathrm{kg}^{-1}$ for Melipona fasciculata honey (HOLANDA et al., 2012), from 31.8 to $33.2 \mathrm{meq} \cdot \mathrm{kg}^{-1}$ for Melipona subnitida honey (ALMEIDA-MURADIAN et al., 2013) and from 52.0 to $82,0 \mathrm{meq} \cdot \mathrm{kg}^{-1}$ in honey from various meliponines (MONTE et al., 2013).

Despite the similar values of acidity, the average $\mathrm{pH}$ of the honey from the Munim Catchment Area was statistically higher $(p \leq 0.05)$ than that of the honey from the Pericumã Catchment Area (Table 2). In studies with honey from Melipona sp and Melipona quadrifasciata, their respective $\mathrm{pH}$ values varied from 3.2 to 5.7 and from 3.5 to 6.6 respectively (CARVALHO et al., 2009; LAGE et al., 2012). Brazilian law does not give reference values for $\mathrm{pH}$ for Apis mellifera honey as a parameter for quality control, but the $\mathrm{pH}$ and acidity are related to greater or lesser susceptibility to development of microbial spoilage (DENARDI et al., 2005). The $\mathrm{pH}$ of the honey is influenced by the $\mathrm{pH}$ of the nectar, the soil or association of other plants in the composition of the product, besides mandibular substances of the bees that, when the bees are transporting the honey to the hive, mix with the nectar, changing this value (CARVALHO et al., 2009).

Table 2 shows the high dispersion of the results for non-reducing sugars, insoluble solids, ash, acidity and $\mathrm{pH}$. This dispersion is the result of the different municipalities and the time of year when the samples were collected but not due to errors of analysis. Despite this limitation to this study, this indicateds the importance of considering a range of values for the quality parameters to be defined when elaborating specific legislation for meliponine honey, in order to allow the products to meet appropriate legal requirements.

The principal component analysis showed that the first and the second main component explained, respectively, 43.6 and $19 \%$, totaling 63.3 $\%$ of the data variation (Figure 1). The first principal component was explained by two groups of variables: one made up of soluble solid content, $\mathrm{pH}$ and ash (factorial charges $\geq 0.7$ ) and another composed of moisture (factorial charge $\leq-0.70$ ). Soluble solid content, $\mathrm{pH}$ and ash have strong positive correlation with each other but are negatively correlated with moisture. The second principal component was not explained by any variable, if it is considered that strong correlations should have a factorial load $\geq 0.7$.

In general, honey samples from the

Munim Water Catchment Area were described by the soluble solid content, $\mathrm{pH}$ and ash, which corroborated the results presented in table 2, except for the soluble solid content, which was statistically the same for the two regions. The honey samples from the Pericumã Catchment Area were described in general by moisture, which also corroborated the results in table 2. It was also seen that some samples from Munim and some from Pericumã were plotted within those from the other region, probably due to discrepancy in the results, which was also observed in the wide dispersion of the results in table 2 . 


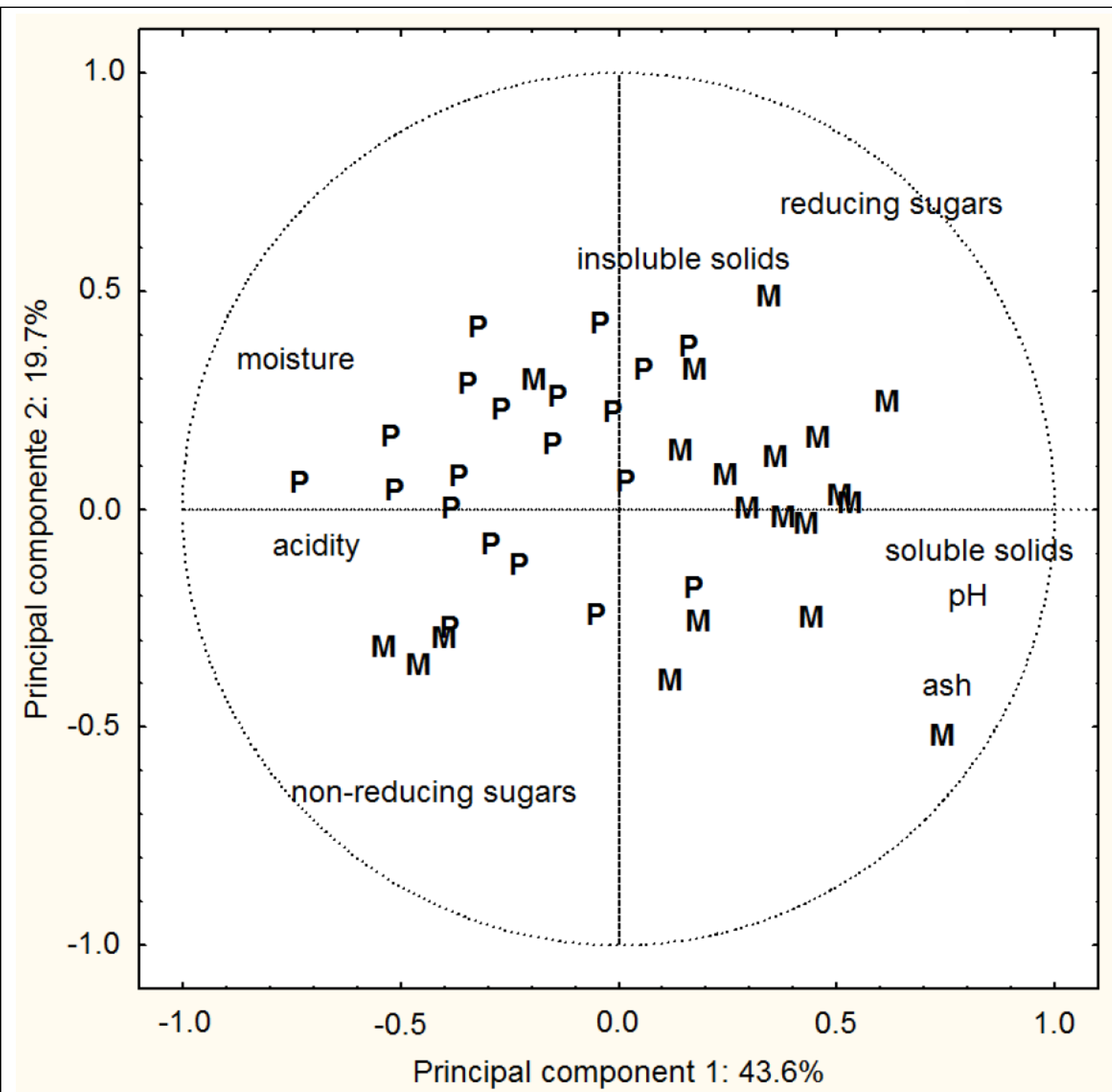

Figure 1 - Correlations between physical-chemical characteristics and description of the Tiúba honeys through principal component analysis. Legend: $\mathrm{M}=$ Munim Water Catchment Area; $\mathrm{P}=$ Pericumã Water Catchment Area.

\section{CONCLUSION}

Samples of Tiúba honey were microbiologically fit for human consumption, except for one sample from the Pericumã Catchment Area. The honeys from both Catchment Area presented mean values of moisture and non-reducing sugars above the determined by the Brazilian legislation to honey of Apis mellifera, as well mean values of reducing sugars below the legislation. Moreover, honeys were differently described depending on the geographic origin, since the honeys from the Munim Water Catchment Area were described by the soluble solid content, $\mathrm{pH}$ and ash, while the honeys from the Pericumã Catchment Area were described by the moisture. Therefore, the honey samples from the two regions did not conform to the Brazilian legislation for Apis mellifera honey for some physical-chemical characteristics, which demonstrates the need to have specific legislation for meliponine honeys. 


\section{ACKNOWLEDGEMENTS}

The authors are grateful to Coordenação de Aperfeiçoamento de Pessoal de Nível Superior (CAPES) for the scholarship granted (number 20130030) and to the Fundação de Amparo à Pesquisa e ao Desenvolvimento Científico e Tecnológico do Maranhão (FAPEMA, grant number 03630/2013) for financing the research.

\section{DECLARATION OF CONFLICT OF} INTEREST

The authors declare no conflict of interest.

\section{REFERENCES}

ALMEIDA-MURADIAN, L.B. et al. Comparative study of the physicochemical and palynological characteristics of honey from Melipona subnitida and Apis mellifera. International Journal of Food Science and Technology, v. 48, n. 8, p. 1698-1706, aug. 2013. Available from: <http://onlinelibrary.wiley.com/ doi/10.1111/ijfs.12140/abstract>. Accessed: Jan. 05, 2018. doi: 10.1111/ijfs. 12140 .

ANACLETO, D.A. et al. Composition of the honey of samples originated from Jataí bees (Tetragonisca angustula latreille, 1811). Ciência e Tecnologia de Alimentos, v. 29, n. 3, p. 535-541, jul.set. 2009. Available from: <http://www.scielo.br/pdf/cta/v29n3/ a13v29n3.pdf>. Accessed: Jan. 05, 2018. doi: 10.1590/S010120612009000300013.

ANDRADE, E.C.B. Análise de alimentos, uma visão química da nutrição. São Paulo: Varela, 2006.

AOAC (Association of Official Analytical Chemists). Official methods of analysis. Washington: AOAC International, 2000. $17^{\text {th }} \mathrm{ed}$.

ARAÚJO, J.S. et al. Chemical composition and biological activities of mono-and heterofloral bee pollen of different geographical origins. International Journal of Molecular Sciences, v. 18, n. 5 , may, 2017. Available from: <https://www.ncbi.nlm.nih.gov/pmc/ articles/PMC5454834/>. Accessed: Jan. 05, 2018. doi: 10.3390/ ijms18050921.

BARROS, M.H.M.R. et al. Pollen analysis of geopropolis of Melipona (Melikerria) fasciculata Smith, 1854 (Meliponini, Apidae, Hymenoptera) in areas of Restinga, Cerrado and flooded fields in the state of Maranhão, Brazil. Grana, v. 52, n. 2, p. 8192, 2013. Available from: <http://www.tandfonline.com/doi/pdf/ 10.1080/00173134.2013.765909>. Accessed: Jan. 05, 2018. doi: $10.1080 / 00173134.2013 .765909$.

BOGDANOV, S. et al. Honey quality and international regulatory standards: review by the International Honey Commission. Bee World, v. 80, n. 2, p. 61-69, 1999. Available from: <http://www. tandfonline.com/doi/abs/10.1080/0005772X.1999.11099428>. Accessed: Jan. 05, 2018. doi: 10.1080/0005772X.1999.11099428.

BRASIL. Ministério da Agricultura e Abastecimento. Instrução Normativa $\mathrm{n}^{\circ} 11$, de 20 de outubro de 2000. Regulamento técnico de identidade e qualidade do mel. Brasília: Diário Oficial da União.

BRASIL. Agência Nacional de Vigilância Sanitária. Resolução $\mathrm{n}^{\circ} 12$, de 2 de janeiro de 2001. Regulamento técnico sobre padrões microbiológicos para alimentos. Brasília: Diário Oficial da União.
CAC (Codex Alimentarius Commission). CODEX Standard for Honey (CODEX STAN 12-1981). Revisions 1987 and 2001. Online. Available from: <http://www.fao.org/fao-whocodexalimentarius/en/>. Accessed: Jan. 05, 2018.

CAMARGO, R.C.R. et al., Stingless bee honey: technical regulation proposal. Brazilian Journal of Food Technology, v. 20, e2016157, 2017. Available from: <http://www.scielo.br/pdf/ bjft/v20/1981-6723-bjft-1981-672315716.pdf > . Accessed: Jan. 05, 2018. doi: 10.1590/1981-6723.15716.

CAMPOS, F.S. et al. Physico-chemical parameters of the honey of stingless bee Melipona scutellaris produced in the Paraíba. Zootecnia, v. 7, p. 186-190, 2010.

CARVALHO, C.A.L. et al. Physicochemical characteristics and sensory profile of honey samples from stingless bees (Apidae: Meliponinae) submitted to a dehumidification process. Anais da Academia Brasileira de Ciências, v. 81, n. 1, p. 143-149, 2009. Available from: <http://www.scielo.br/pdf/aabc/v81n1/ a15v81n1.pdf>. Accessed: Jan. 05, 2018. doi: 10.1590/S000137652009000100015

CARVALHO, G.C.A. et al. Flora de importância polínica utilizada por Melipona (Melikerria) fasciculata Smith, 1854 (Hymenoptera: Apidae: Meliponini) em uma área de floresta amazônica na região da baixada maranhense, Brasil. Oecologia Australis, v. 20, n. 1, p. 58-68, 2016. Available from: <http://www. oecologiaaustralis.org/ojs/index.php/oa/article/view/894/1049>. Accessed: Jan. 09, 2018.

DENARDI, C.A.S. et al. Avaliação da atividade de água e da contaminação por bolores e leveduras em mel comercializado na cidade de São Paulo, Brasil. Revista do Instituto Adolfo Lutz, v. 64, n. 2, p 219-222, 2005. Available from: <http://periodicos.ses. sp.bvs.br/pdf/rial/v64n2/v64n2a12.pdf>. Accessed: Jan. 05, 2018.

ESTEVINHO, L.M. et al. Characterization of Lavandula spp. honey using multivariate techniques. PLoS One, v. 11, n. 9 , e0162206, 2016. Available from: <http://journals.plos.org/plosone/ article $/$ file $?$ id $=10.1371 /$ journal . pone $.0162206 \&$ type $=$ printable $>$. Accessed: Jan. 05, 2018. doi: 10.1371/journal.pone.0162206.

FEÁS, X. et al. Characterization of artisanal honey produced on the Northwest of Portugal by melissopalynological and physicochemical data. Food and Chemical Toxicology, v. 48, n. 12, p. 3462-3470, 2010a. Available from: <https://bibliotecadigital.ipb. pt/bitstream/10198/4524/1/iglesias.pdf>. Accessed: Jan. 05, 2018. doi: 10.1016/j.fct.2010.09.024.

FEÁS, X. et al. Palynological and physicochemical data characterisation of honeys produced in the Entre-Douro e Minho region of Portugal. International Journal of Food Science and Technology, v. 45, n. 6, p. 1255-1262, jun. 2010b. Available from: <http://onlinelibrary.wiley.com/doi/10.1111/j.13652621.2010.02268.x/abstract>. Accessed: Jan. 05, 2018. doi: 10.1111/j.1365-2621.2010.02268.x.

GEPLAN (Gerência de Planejamento e Desenvolvimento Econômico). Atlas do Maranhão. São Luís: GEPLAN, 2002.

GOIS, G.C. et al. Composição do mel de Apis mellifera: Requisitos de qualidade. Acta Veterinaria Brasilica, v. 7, n. 2, p. 137-147, 2013. Available from: $<$ https://periodicos.ufersa.edu.br/index.php/ acta/article/view/3009>. Accessed: Jan. 05, 2018. doi: 10.21708/ avb.2013.7.2.3009. 
GUERRINI, A. et al. Ecuadorian stingless bee (Meliponinae) honey: A chemical and functional profile of an ancient health product. Food Chemistry, v. 114, n. 4, p. 1413-1420, jun. 2009. Available from: <https://www.sciencedirect.com/science/article/ pii/S0308814608013678>. Accessed: Jan. 05, 2018. doi: 10.1016/j. foodchem.2008.11.023.

HOLANDA, C.A. et al. Qualidade dos méis produzidos por Melipona fasciculata Smith da região do cerrado maranhense. Química Nova, v. 35, n. 1, p. 55-58, 2012. Available from: $<$ http://www.scielo.br/scielo.php?script $=$ sci arttext\&pid $=$ S0100-40422012000100011 $>$. Accessed: Jan. 05, 2018. doi: $10.1590 / \mathrm{S} 0100-40422012000100011$.

IGLESIAS, A. et al. Comprehensive study of honey with protected denomination of origin and contribution to the enhancement of legal specifications. Molecules, v. 17, n. 7, p. 8561-8577, jul. 2012. Available from: <https://pdfs.semanticscholar.org/51a2/82c926c 67ff2838118573999f9e8e4b7cbf0.pdf>. Accessed: Jan. 05, 2018. doi: $10.3390 /$ molecules 17078561 .

IAL (Instituto Adolfo Lutz). Métodos físico-químicos para análise de alimentos. São Paulo: Instituto Adolfo Lutz, 2005. $4^{\mathrm{a}}$ ed.

ICMSF (International Commission on Microbiological Specifications for Foods). Microrganismos em alimentos: utilização de dados para avaliação do controle de processo e aceitação de produto. São Paulo: Blucher, 2002.

JAGANATHAN, S.K. et al. Apoptotic effect of eugenol in human colon cancer cell lines. Cell Biology International, v. 35, n. 6, p. 607-615, jun. 2011. Available from: <http://onlinelibrary.wiley. com/doi/10.1042/CBI20100118/abstract>. Accessed: Jan. 05, 2018. doi: 10.1042/CBI20100118.

KWAKMAN, P.H. et al. How honey kills bacteria. The FASEB Journal, v. 24, n. 7, p. 2576-2582, 2010. Available from: <http:// www.fasebj.org/content/24/7/2576.long>. Accessed: Jan. 05, 2018. doi: 10.1096/fj.09-150789.

LAGE, L.G.A. et al. Honey physicochemical properties of three species of the brazilian Melipona. Anais da Academia Brasileira de Ciências, v. 84, n. 3, p. 605-608, sep. 2012. Available from: <http://www.scielo.br/pdf/aabc/v84n3/ a op 5312 .pdf $>$. Accessed: Jan. 05, 2018. doi: 10.1590/S000137652012005000051 .

MONTE, A.M. et al. Qualidade de méis de abelhas nativas sem ferrão do estado do Piauí, Brasil. Revista Brasileira de Medicina Veterinária, v. 35, n. 1, p. 48-54, jan/mar. 2013. Available from: $<$ http://www.rbmv.com.br/pdf_artigos/02-07-2013_1121RBMV\%20009.pdf>. Accessed: Jan. 05, 2018.
NASCIMENTO, A.S. et al. Physical-chemical parameters of honey of stingless bee (Hymenoptera: Apidae). American Chemical Science Journal, v. 7, n. 3, p. 139-149, 2015. Available from: <http://www.journalrepository.org/media/journals/ ACS J_16/2015/Apr/Nascimento 732015 ACSj 17547. pdf>. Accessed: Jan. 05, 2018. doi: 10.9734/ACSj/2015/17547.

OLIVEIRA, E.N.A.; SANTOS, D.C. Análise físico-química de méis de abelhas africanizada e nativa. Revista do Instituto Adolfo Lutz, v. 70, n. 2, p. 132-138, abr/jun. 2011. Available from: <http://periodicos. ses.sp.bvs.br/pdf/rial/v70n2/v70n2a05.pdf>. Accessed: Jan. 05, 2018.

PIRES, J. et al. Pollen spectrum and physico-chemical attributes of heather (Erica sp.) honeys of north Portugal. Journal of the Science of Food and Agriculture, v. 89, n. 11, p. 1862-1870, aug. 2009. Available from: <http://onlinelibrary.wiley.com/ doi/10.1002/jsfa.3663/abstract>. Accessed: Jan. 05, 2018. doi: $10.1002 /$ jsfa. 3663 .

SILVA, A.S. et al. Classification of honeys from Pará State (Amazon Region, Brazil) produced by three different species of bees. Journal of the Brazilian Chemical Society, v. 24, n. 7, p. $1135-1145,2013$. Available from: <http://www.scielo.br/ pdf/jbchs/v24n7/v24n7a07.pdf>. Accessed: Jan. 05, 2018. doi: 10.5935/0103-5053.20130147.

SOUSA, J.M.B. et al. Physicochemical aspects and sensory profile of stingless bee honeys from Seridó region, State of Rio Grande do Norte, Brazil. Semina: Ciências Agrárias, v. 34, n. 4, p. 17651774, jul/ago. 2013. Available from: < http://www.uel.br/revistas/ uel/index.php/semagrarias/article/view/13700>. Accessed: Jan. 05, 2018. doi: 10.5433/1679-0359.2013v34n4p1765.

SOUSA, J.M.B. et al. Sugar profile, physicochemical and sensory aspects of monofloral honeys produced by different stingless bee species in Brazilian semi-arid region. LWT - Food Science and Technology, v. 65, p. 645-651, jan. 2016. Available from: $<$ https:// www.sciencedirect.com/science/article/pii/S0023643815301523>. Accessed: Jan. 05, 2018. doi: 10.1016/j.lwt.2015.08.058.

SOUZA, B.A. et al. Caracterização do mel produzido por espécies de Melipona Illiger, 1806 (Apidae: Meliponini) da região nordeste do Brasil: 1. Características físico-químicas. Química Nova, v. 32, n. 2, p. 303-308, 2009. Available from: <http://www.scielo.br/pdf/ qn/v32n2/v32n2a07.pdf>. Accessed: Jan. 05, 2018. doi: 10.1590/ S0100-40422009000200007.

WATANABE, K. et al. Anti-influenza viral effects of honey in vitro: potent high activity of manuka honey. Archives of Medical Research, v. 45, n. 5,p. 359-365, jul. 2014. Available from: $<$ https:// www.sciencedirect.com/science/article/pii/S0188440914001106>. Accessed: Jan. 05, 2018. doi: 10.1016/j.arcmed.2014.05.006. 